\title{
KESANTUNAN BERBAHASA DALAM INTERAKSI PEMBELAJARAN BAHASA JAWA DI SMP N 1 BANYUMAS
}

\author{
Astiana Ajeng Rahadini ${ }^{1)}$, Suwarna ${ }^{2)}$ \\ Universitas Negeri Surakarta ${ }^{1)}$, Universitas Negeri Yogyakarta ${ }^{2)}$ \\ astiana.ajeng@gmail.com ${ }^{1)}$, suwaranjawa@yahoo.com ${ }^{2)}$
}

\begin{abstract}
Abstrak
Penelitian ini bertujuan untuk mendeskripsikan dan menganalisis bentuk, nilai, dan fungsi kesantunan berbahasa Jawa dalam interaksi antara guru dan siswa ketika pembelajaran bahasa Jawa di SMP N 1 Banyumas serta implikasinya bagi pembelajaran. Jenis pendekatan yang digunakan, yaitu deskriptif. Metode pengumpula data yang digunakan, yaitu metode simak bebas libat cakap, teknik rekam, dan catat. Hasil penelitian menunjukkan: (1) bentuk kesantunan berbahasa Jawa direpresentasikan dalam modus deklaratif atau kalimat berita, modus interogatif atau kalimat pertanyaan, modus imperatif atau kalimat perintah yang merepresentasikan jenis tindak tutur representatif, direktif, ekspresif, dan komisif; (2) Nilai kesantunan berbahasa dilihat dari isi tuturan yang mematuhi prinsip kesantunan berbahasa Jawa dan penggunaan unggah-ungguh basa; (3) Fungsi kesantunan berbahasa meliputi fungsi kompetitif dan fungsi menyenangkan. (4) Implikasi hasil penelitian meliputi penggunaan bentuk-bentuk kesantunan berbahasa Jawa untuk menyamankan interaksi pembelajaran, peningkatan nilai kesantunan tuturan dengan memperhatikan isi tuturan dan penggunaan unggahungguh basa yang benar, dan penggunaan fungsi kesantunan menyenangkan dan ungkapan penanda kesantunan untuk tindak tutur direktif dan ekspresif.
\end{abstract}

Kata kunci: kesantunan berbahasa Jawa, interaksi pembelajaran

\section{POLITENESS IN JAVANESE LANGUAGE TEACHING INTERACTION AT SMP N 1 BANYUMAS}

\begin{abstract}
The aim of this study is to describe the forms, values, and functions of politeness within the interaction of teachers and their students especially in Javanese language teaching at SMP N 1 Banyumas, and its implications for learning. The data collection techniques of this study were observing, recording, and note taking. The results of this study showed: (1) the form of Javanese politeness is represented in the form of statements, questions, commands represented in the type of speech acts of directive, expressive, and commissive; (2) the Javanese politeness value is seen from the contents of the speech which adhere to the principles of Javanese politeness and the use of unggah-ungguh basa; (3) the function of language politeness invented in this study consists of competitive and pleasing functions; (4) the implications of the study include the use of Javanese language politeness forms to please language learning interactions, the enhancement of politeness value in speech production by concerning the content of speech productions and the use of proper unggah-ungguh basa, and also the use of pleasing politeness function and expression signified by politeness for directive and expressive speech acts.
\end{abstract}

Keywords: Javanese politeness, learning interactions. 


\section{PENDAHULUAN}

Bahasa Jawa mengandung nilai budi pekerti yang luhur (Harjawiyana dan Supriya, 2009, p.9). Nilai luhur bahasa Jawa tampak pada rasa kesantunan dan kepekaan rasa yang berdasar pada prinsip menghormati orang lain. Ibid melalui Eelen (2001, p.5) menyebutkan kesantunan sangat penting bagi struktur kehidupan sosial dan masyarakat, sebagai ekspresi hubungan sosial)." Kesantunan berbahasa merupakan salah satu cara untuk mewujudkan kerukunan dalam hidup bermasayarakat.

Kesantunan berbahasa adalah sebuah sistem hubungan interpersonal yang didesain untuk memfasilitasi interaksi dengan meminimalisasi pertentangan dan konfrontasi yang melekat pada manusia (Lakoff melalui Eelen, 2001, p.2). Penghindaran konflik ini dilakukan dengan cara berbahasa yang menyenangkan lawan tuturnya. Mewujudkan bahasa yang santun tidak dapat dilepaskan dari konteks tutur dan faktor sosial budaya yang melatarinya.

Para ahli telah mengkaji tentang kesantunan berbahasa secara universal dan merumuskan berbagai macam strategi untuk menciptakan kesantunan dalam berkomunikasi. Ahli yang terkenal dengan kajiannya tentang kesantunan berbahasa antara lain Leech (1993), BrownLevinson (1987), dan Robin T. Lakoff. Namun, sebenarnya kriteria penilaian kesantunan suatu bahasa tidak pernah lepas dari budaya yang mengikatnya. Ada aspek-aspek tertentu dalam suatu kebudayaan yang tidak dimiliki oleh kebudayaan lain (Sukarno, 2010, p.59). Meskipun tidak menutup kemungkinan adanya prinsip dan kriteria kesantunan yang sama dengan kebudayaan lain.

Demikian juga dengan bahasa Jawa yang tidak terlepas dari budaya Jawa. Hal ini menyebabkan bahasa Jawa memiliki kriteria-kriteria penentu kesantunannya sendiri. Asim Gunarwan (2005) telah merumuskan prinsip kesantunan berbahasa Jawa. Berdasarkan prinsip kesantunan berbahasa tersebut dan dipadukan dengan prinsip kesantunan secara universal, diperoleh kriteria kesantunan berbahasa Jawa. Kriteria kesantunan berbahasa Jawa meliputi kesantunan pada aspek isi tuturan dan kesantunan pada penggunaan unggah-ungguh basa yang didukung oleh faktor non-kebahasaan (gerak-gerik tubuh, tinggi rendah nada bicara, ekspresi muka). Namun, dalam penelitian ini difokuskan pada aspek kebahasaan saja.
Untuk aspek kebahasaan lebih menekankan pada bentuk, nilai, dan fungsi kesantunan berbahasa. Bentuk kesantunan berbahasa dapat dilihat dari bentuk lokusi tindak tuturnya, bermodus deklaratif atau kalimat berita, bermodus interogatif atau kalimat pertanyaan, atau bermodus imperatif atau kalimat perintah. Nilai kesantunan berbahasa dapat dilihat dari ilokusi dan isi tuturan yang mematuhi prinsip-prinsip kesantunan berbahasa Jawa dan ketepatan penggunaan unggah-ungguh basa. Fungsi kesantunan berbahasa dapat dilihat dari perlokusi atau efek yang ditimbulkan dari penggunaan tindak tutur tersebut.

Namun, semua penentuan nilai kesantunan berbahasa juga sangat dipengaruhi oleh konteks tutur yang melingkupinya. Dell Hymes melalui Wardhaugh (1986, pp.245-246) menyebutkan akronim SPEAKING untuk menjelaskan komponen-komponen yang termasuk dalam konteks tutur, yang meliputi $\mathrm{S}$ (Setting and Scene), P (Participant), E (Ends), A (Act Sequences), K (Key), I (Instrumentalities), N (Norm), G (Genre). Agar menghasilkan tuturan yang santun, penutur harus memperhatikan konteks tutur tersebut ketika berkomunikasi.

Interaksi dalam proses pembelajaran juga termasuk peristiwa komunikasi yang membutuhkan kesantunan berbahasa. Masalah tentang bentuk, nilai, dan fungsi kesantunan berbahasa Jawa sebaiknya dipahami dengan baik oleh guru dan siswa untuk menciptakan kenyamanan dalam proses pembelajaran. Kesantunan berbahasa akan memperlancar proses transfer pengetahuan karena guru dan siswa berada dalam situasi yang kondusif dan menyenangkan. Bahasa santun yang digunakan guru dalam berinteraksi dengan siswa juga akan memberikan input atau contoh konkret penggunaan bahasa yang baik dan santun dalam berkomunikasi kepada siswa.

Melihat peran bahasa di dalam kelas sebagai media transfer pengetahuan, maka bahasa dalam ranah pembelajaran lebih menekankan fungsi komunikasi daripada fungsi keindahan bahasa. Pemahaman pengetahuan atau pesan yang disampaikan melalui bahasa yang digunakan oleh guru dan siswa lebih ditekankan. Selain itu, tuturan di dalam kelas bersifat formal dan transaksional. Namun, penggunaan bahasa dalam interaksi pembelajaran tetap harus memperhatikan kesantunan berbahasa agar komunikasi tetap beretika, yaitu dengan menggunakan unggah-ungguh basa Jawa yang umum digunakan dalam proses pembelajaran, seperti ragam ngoko, ngoko alus, krama, dan krama inggil. 
Dari penjelasan tersebut dapat dilihat pentingnya kesantunan berbahasa dalam berkomunikasi dan berinteraksi, termasuk komunikasi yang terjadi antara guru dan siswa di dalam kelas. Namun, di era globalisasi seperti sekarang ini pemahaman dan penguasaan kesantunan berbahasa semakin menurun. Hal ini dapat dilihat pada contoh nyata di lapangan.

Seorang guru memberikan latihan soal mendadak menjelang ujian akhir semester. Namun, siswa justru meremehkan tugas tersebut. Mereka mengerjakan latihan soal dengan memakai lintingan (seperti kocokan pada arisan). Jawaban apa yang keluar kemudian dituliskan pada lembar jawab. Terlihat sekali bahwa siswa tidak berpikir dalam mengerjakan soal tersebut. Kemudian guru menegur siswa tersebut: 'Bijine nggarap latihan soal kuwi bisa kanggo nambahnambah nilai rapotmu' (Nilai dari mengerjakan soal latihan ini dapat untuk menambah nilai rapotmu). Namun, di luar dugaan siswa justru menjawab: 'Lah ben' (Lah, biar). Berdasarkan jawaban siswa dalam konteks di atas terlihat bahwa isi tuturan siswa tidak menunjukkan adanya kesantunan karena meremehkan soal latihan dan menantang guru sehingga seolahseolah tidak membutuhkan nilai. Padahal guru sudah berusaha menyampaikan kritikan atau teguran dalam bentuk tuturan yang santun. Isi tuturan siswa yang demikian menyebabkan nilai kesantunan berbahasa menurun.

Menurunnya tingkat kesantunan siswa terhadap guru juga terlihat dari tingkat penghormatan siswa terhadap guru yang semakin menurun. Di saat sekarang ini, lebih banyak dijumpai siswa yang berbicara kepada guru seperti berbicara kepada teman sebaya. Misalnya, berbicara kepada guru menggunakan bahasa ngoko disertai perilaku yang tidak menunjukkan penghormatan. Hal ini disebabkan penguasaan unggah-ungguh basa yang masih rendah.

Misalnya, dalam suatu interaksi kelas siswa menyebutkan "Asma kula Deswita Pratiwi." (Nama saya Deswita Pratiwi). Penggunaan kata asma yang berati nama tetapi ditujukan untuk dirinya sendiri seharusnya diganti kata nami. Kata asma digunakan untuk orang yang lebih tua. Kesalahan dalam penggunaan unggahungguh basa ini menyebabkan menurunnya nilai kesantunan berbahasa Jawa. Dari fenomena tersebut dapat dilihat bahwa guru dan siswa kurang memahami pentingnya unggah-ungguh basa dalam meningkatan kesantunan bahasa suatu tuturan.
Berdasarkan wacana dan pertimbangan pentingnya penelitian tentang kesantunan berbahasa Jawa seperti uraian tersebut, maka peneliti tertarik untuk meneliti permasalahan "Kesantunan Berbahasa Jawa dalam interaksi antara guru dan siswa khususnya ketika pembelajaran bahasa Jawa di SMP N 1 Banyumas." Kualitas prestasi sekolah yang tinggi dan usia peserta didik (remaja awal) merupakan salah satu pertimbangan penelitian.

Penelitian tentang kesantunan berbahasa dalam pembelajaran antara lain telah dilakukan oleh Sugiyanto (2011) dalam skripsinya yang berjudul Realisasi Kesantunan Berbahasa antara Guru dan Staff SMA Muhammadiyah Andong dan Wang (2008) dalam disertasinya yang berjudul "The Politeness Effect: Pedagogical Agents and Learning Outcomes. Berikut ini diuraikan secara ringkas garis besar kajian mereka.

Penelitian yang dilakukan oleh Sugiyanto (2011) bertujuan untuk mengkaji gambaran perwujudan kesantunan dalam berbahasa antara kepala sekolah, guru, dan staf tata usaha di SMA Muhammadiyah 4 Andong. Teknik pengumpulan data menggunakan teknik simak dengan teknik dasar cakap, rekam, dan pengamatan berpartisipasi. Hasil penelitian yang dilakukan oleh Sugiyanto menunjukkan bahwa di dalam berkomunikasi sehari-hari yang dilakukan oleh karyawan SMA Muhammadiyah 4 Andong, individu yang memegang peranan penting atau jabatan di sekolah, dalam berkomunikasi seharihari tingkat kesantunannya relatif rendah. Untuk karyawan biasa seperti guru dan pegawai tata usaha, tingkat kesantunanya lebih tinggi.

Sementara itu, penelitian yang dilakukan oleh Wang (2008) dilakukan untuk menguji hipotesis: agen-agen pendidikan dengan kepandaian strategi sosial dapat mempengaruhi hasil pembelajaran. Penelitian dilakukan dengan pengujian di dua lingkungan pembelajaran yang berbeda, yaitu pada lingkungan pembelajar teknik industri dan pembelajar bahasa. Hasil penelitian mendukung kebenaran hipotesis yang menunjukkan bahwa kemampuan strategi sosial berpengaruh pada hasil atau keluaran pembelajaran.

Apabila dibandingkan dengan dua penelitian tersebut, penelitian ini memiliki persamaan dan perbedaan. Persamaan terletak pada inti kajian, yaitu meneliti kesantunan berbahasa dalam pembelajaran. Sementara itu, perbedaan dapat dilihat pada tujuan dan cara penelitian. Penelitian ini bertujuan untuk mendeskripsikan dan 
menganalisis: (1) bentuk kesantunan tindak tutur berbahasa Jawa yang muncul dalam interaksi antara guru dan siswa, (2) nilai kesantunan tindak tutur berbahasa Jawa dalam interaksi antara guru dan siswa, (3) fungsi kesantunan tindak tutur berbahasa Jawa dalam interaksi antara guru dan siswa, (4) implikasi dari gambaran kesantunan tindak tutur berbahasa Jawa yang ditemukan dalam penelitian bagi pembelajaran bahasa Jawa. Semua aspek tersebut diteliti dalam konteks pembelajaran bahasa Jawa di SMP N 1 Banyumas. Untuk cara atau metode penelitian dijelaskan pada bab berikut ini.

\section{METODE}

\section{Jenis Penelitian}

Jenis penelitian ini adalah penelitian deskriptif. Pemilihan jenis penelitian ini sesuai dengan tujuan penelitian yang ingin mendeskripsikan dan menganalisis bentuk, nilai, dan fungsi kesantunan berbahasa Jawa dalam interaksi antara guru dan siswa khususnya dalam pembelajaran bahasa Jawa di SMP N 1 Banyumas secara apa adanya. Hasil analisis kemudian akan diimplikasikan ke dalam pembelajaran.

\section{Waktu dan Tempat}

Penelitian ini mengambil lokasi di SMP N 1 Banyumas karena mempertimbangkan kualitas sekolah dan peserta didik. Waktu penelitiannya dilakukan mulai bulan Oktober sampai dengan November karena subjek data penelitian ini meliputi kelas 7, 8, dan 9 sehingga proses pengumpulan data lebih longgar dan diharapkan tidak mengganggu proses pembelajaran.

\section{Subjek dan Objek}

Subjek dalam penelitian ini terdiri dari siswa kelas 7, 8, dan 9 SMP N 1 Banyumas dimana masing-masing tingkatan kelas diambil satu kelas beserta dua orang guru bahasa Jawa yang mengampu mata pelajaran bahasa Jawa di kelas tersebut. Variasi umur yang menyebabkan perbedaan kematangan emosional dan mempengaruhi bahasa yang digunakan pada masingmasing tingkatan kelas menjadi salah satu pertimbangan subjek penelitian. Siswa yang berasal dari kelas yang lebih tinggi (kelas 9) biasanya memiliki tuturan yang lebih baik daripada siswa yang berasal dari kelas yang rendah. Objek dalam penelitian ini yaitu semua tuturan berbahasa Jawa yang dituturkan dalam interaksi antara guru dan siswa ketika pembelajaran bahasa Jawa berlangsung di kelas subjek data.

\section{Metode Pengumpulan Data}

Metode pengumpulan data yang digunakan dalam penelitian ini, yaitu metode simak (Simak Bebas Libat Cakap) yang diwujudkan dengan teknik penyadapan dan dilanjutkan dengan teknik rekam dan catat. Perekaman dilakukan dengan menggunakan alat perekam (recorder) dan fasilitas perekam yang terdapat di handphone. Peneliti melakukan pencatatan ketika melakukan penyimakan sekaligus dan mentranskrip data rekaman. Alat (tool) yang digunakan untuk teknik ini, yaitu lembar catatan lapangan. Instrumen yang digunakan dalam penelitian ini yaitu panduan perekaman dan panduan catatan lapangan.

\section{Teknik Analisis Data}

Analisis data menggunakan teknik analisis deskriptif. Tahapan analisis data meliputi tahap pengumpulan data, identifikasi data yang diperoleh; klasifikasi sesuai rumusan masalah; kodifikasi; deskripsi, interpretasi, dan inferensi kesantunan berbahasa berdasarkan bentuk, nilai, dan fungsi kesantunan tindak tutur berbahasa Jawa.

\section{HASIL DAN PEMBAHASAN}

\section{Bentuk Kesantunan Berbahasa Jawa dalam Interaksi Guru dan Siswa}

Bentuk kesantunan berbahasa guru dan siswa yang ditemukan dalam penelitian ini merupakan lokusi yang bermodus deklaratif atau berbentuk kalimat berita/pernyataan, bermodus interogatif atau berbentuk kalimat tanya, bermodus imperatif atau berbentuk kalimat perintah, dan kalimat sambawa. Modus deklaratif atau bentuk kalimat berita berfungsi untuk memberi tahu suatu hal kepada pihak lain. Modus interogatif atau bentuk kalimat tanya digunakan untuk menanyakan suatu informasi, dan modus imperatif atau bentuk kalimat perintah berfungsi untuk menyuruh orang melakukan apa yang termuat dalam tuturannya tersebut.

Bentuk tindak tutur tersebut merepresentasikan jenis ilokusi tindak tutur tertentu. Jenis ilokusi tindak tutur yang ditemukan dalam penelitian ini meliputi jenis tindak tutur representatif, tindak tutur direktif, tindak tutur ekspresif, dan tindak tutur komisif. Tindak tutur direktif merupakan jenis tindak tutur yang bertujuan agar mitra tutur melakukan tindakan yang disebutkan dalam tuturan penutur. Tindak tutur ekspresif merupakan tindak tutur yang bertujuan untuk memberikan evaluasi, dan tindak tutur komisif 
merupakan tindak tutur yang bertujuan untuk mengikat penuturnya.

Namun, tidak semua bentuk tindak tutur lokusi ini dituturkan sesuai dengan fungsi komunikatif atau jenis ilokusi tindak tutur yang terkandung di dalam tuturan sehingga bentuk tindak tutur yang tercipta adalah bentuk tindak tutur tidak langsung. Hal ini dilakukan dengan tujuan untuk memperlunak daya ilokusi sehingga tuturan menjadi lebih santun. Pelunakan daya ilokusi membuat maksud penutur tidak tersampaikan secara langsung atau terselubung sehingga tidak terkesan 'terang-terangan'. Penggunaan bentuk ini memberikan manfaat untuk menjaga hubungan baik dengan mitra tutur karena apa yang diungkapkan oleh penutur tidak menyakiti mitra tutur.

Bentuk kesantunan berbahasa dalam tindak tutur guru dan siswa ketika berinteraksi dalam pembelajaran bahasa Jawa di kelas direpresentasikan dalam tuturan bermodus deklaratif atau berbentuk kalimat berita, bermodus interogatif atau berbentuk kalimat pertanyaan, bermodus imperatif atau berbentuk kalimat perintah, dan berbentuk kalimat sambawa. Guru menggunakan modus deklaratif atau bentuk kalimat berita untuk mempresentasikan jenis tindak tutur direktif berupa tindak menyuruh, menyarankan, meminta, mengklarifikasi, melarang, mempersilakan, memuji, mengkritik; tindak tutur ekspresif berupa tindak memuji dan mengkrtik; tindak komisif berupa tindak berjanji dan mengancam. Sementara itu, siswa menggunakan modus deklaratif atau tuturan berbentuk kelimat berita untuk mempresentasikan jenis tindak tutur direktif berupa tindak meminta, mengklarifikasi, dan tindak tutur ekspresif berupa tindak mengeluh dan mengkritik.

Guru menggunakan modus interogatif atau tuturan berbentuk kalimat pertanyaan untuk merepresentasikan jenis tindak tutur direktif berupa tindak mengklarifikasi, menyuruh, meminta, menantang, melarang; tindak tutur ekspresif berupa tindak mengeluh dan mengkritik. Sementara itu, siswa menggunakan modus interogatif atau tuturan berbentuk kalimat pertanyaan untuk merepresentasikan jenis tindak tutur direktif berupa tindak meminta, menyuruh, mengklarifikasi, menantang.

Modus imperatif atau tuturan berbentuk kalimat perintah digunakan guru untuk merepresentasikan tindak tutur menyuruh, mengajak, menuntut, meminta, menyarankan, melarang, mempersilakan; tindak tutur ekspresif berupa tindak memuji. Sementara itu siswa mengguna- kan modus imperatif untuk merepresentasikan tindak Menyarankan, meminta, menyuruh. Guru juga menggunakan tuturan berbentuk kalimat sambawa untuk merepresentasikan jenis tindak tutur representatif berupa fungsi mengharap; tindak tutur direktif berupa tindak mengharap, menyarankan; tindak tutur ekspresif berupa tindak memuji, mengeluh; dan tindak tutur komisif berupa tindak berjanji.

Bentuk berita direktif dan bentuk pertanyaan direktif untuk tujuan menyuruh lebih santun daripada bentuk perintah direktif karena daya ilokusi yang lebih lunak daripada bentuk direktif. Misalnya, untuk pemberian perintah. Ilokusi direktif yang disampaikan dalam modus deklaratif dan modus interogatif terasa lebih santun daripada ilokusi direktif yang disampaikan dalam modus imperatif. Ilokusi direktif pada modus deklaratif dan interogatif menempuh jarak yang lebih panjang sehingga tidak langsung mengenai mitra tutur dan mitra tutur memiliki lebih banyak kesempatan untuk merespon ilokusi direktif tersebut. Berbeda dengan ilokusi direktif pada modus imperatif yang secara langsung mengenai mitra tutur sehingga mitra tutur pun langsung merasa tertuntut dan memiliki kesempatan yang lebih sedikit untuk merespon tuturan penutur tersebut.

Pada beberapa peristiwa tutur yang terekam, guru dan siswa sudah menggunakan bentuk-bentuk kesantunan berbahasa Jawa ini. Jadi, hanya perlu untuk meningkatkan intensitasnya. Bentuk-bentuk tindak tutur yang santun akan menyamankan proses interaksi dan komunikasi di dalam kelas. Tidak ada pihak yang tersakiti ketika guru dan siswa berinteraksi sehingga tujuan pembelajaran pun dapat berjalan lancar.

\section{Nilai Kesantunan Berbahasa Jawa dalam Interaksi Guru dan Siswa}

Nilai kesantunan berbahasa ditentukan dari penilaian aspek isi tuturan dan penilaian aspek unggah-ungguh basa yang didukung aspek paralingual (ekspresi muka, tinggi rendah nada bicara, gerak-gerik tubuh) yang sesuai dengan konteks tuturnya. Jadi, untuk menentukan nilai kesantunan berbahasa, nilai kesantunan ketiga aspek tersebut tidak dapat dipisahkan. Namun, karena penelitian ini lebih menekankan pada aspek kebahasaan, maka aspek non-kebahasaan atau aspek paralingual tidak termasuk kajian penelitian ini.

Isi tuturan dinilai santun apabila mematuhi prinsip kesantunan berbahasa Jawa. Prinsip kesantunan berbahasa Jawa meliputi prinsip 
kebijaksanaan, prinsip formalitas-tepa selira, prinsip penghargaan dan kerendahan hatiandhap asor, dan prinsip ketidaklangsungan.

Prinsip kebijaksanaan berkaitan dengan sejauh mana tindakan yang dilakukan penutur memberikan keuntungan/kerugian pada mitra tutur. Prinsip formalitas-tepa selira berkaitan dengan cara penyampaian tuturan, apakah penutur memaksa mitra tutur untuk mengikuti apa yang dituturkan atau tidak. Prinsip penghargaan dan kerendahan hati-andhap asor berkaitan dengan respon yang diberikan oleh penutur terhadap tindakan/tuturan mitra tutur, menghargai atau tidak. Kemudian terakhir, prinsip ketidaklangsungan berkaitan dengan daya ilokusi yang terkandung dalam tuturan, diungkapkan secara langsung/terselubung. Nilai kesantunan dilihat dari pencapaian indikator masing-masing prinsip kesantunan yang berkisar dari tidak santun sampai dengan sangat santun. Semakin isi tuturan mematuhi prinsip-prinsip kesantunan berbahasa Jawa tersebut maka nilai kesantunannya semakin tinggi.

Unggah-ungguh basa juga menentukan kesantunan berbahasa dari tuturan yang diucapkan. Penggunaan unggah-ungguh basa yang tepat akan membuat suatu tuturan menjadi santun, begitupun sebaliknya. Hasil penelitian menunjukkan bahwa unggah-ungguh basa yang paling banyak digunakan guru untuk berinteraksi dengan siswa adalah ragam bahasa ngoko alus, kemudian ragam bahasa krama, krama inggil, dan paling sedikit digunakan adalah ragam bahasa ngoko. Sementara itu, untuk tuturan siswa dalam penelitian ini, unggah-ungguh basa yang paling banyak digunakan siswa untuk berinteraksi dengan guru yaitu ragam bahasa krama, kemudian ngoko, ngoko alus, bahasa Indonesia, terakhir krama inggil.

Penilaian kesantunan pada aspek unggahungguh basa, ketika guru berinteraksi dengan siswa menggunakan ragam bahasa krama dan krama inggil maka bernilai sangat santun, apapun motif yang berada di balik penggunaan ragam bahasa tersebut. Hal ini disebabkan guru sangat menghargai siswa. Ketika guru berinteraksi dan berkomunikasi menggunakan ragam bahasa ngoko alus dan ngoko (tidak kasar) maka tuturan guru tersebut bernilai santun karena masih menunjukkan adanya penghargaan guru terhadap siswa.

Sementara itu, pada tuturan kelas 7 dan 8 tidak ditemukan tuturan menggunakan ragam krama inggil karena siswa bersikap kurang aktif. Jika siswa bertanya atau mengemukakan pendapat maka akan menggunakan ragam ngoko, ngoko alus, dan krama. Siswa yang berbicara dengan guru menggunakan ragam bahasa krama inggil maka dikategorikan sangat santun. Jika siswa menggunakan ragam bahasa krama maka dikategorikan santun. Jika siswa menggunakan ragam bahasa ngoko alus dikategorikan cukup santun. Siswa yang berbicara dengan guru menggunakan ragam bahasa ngoko dan bahasa Indonesia (sebenarnya mampu berbahasa Jawa tetapi lebih memilih menggunakan bahasa Indonesia) dikategorikan tidak santun.

\section{Fungsi Kesantunan Berbahasa Jawa dalam Interaksi Guru dan Siswa}

Fungsi kesantunan berbahasa yang ditemukan dalam penelitian ini, yaitu fungsi kesantunan kompetitif dan fungsi kesantunan menyenangkan. Untuk tindak tutur guru, kedua fungsi kesantunan tindak tutur kompetitif dalam penelitian ini direpresentasikan ke dalam jenis tindak tutur direktif yang berupa tindak menantang, menuntut, menyuruh, dan melarang; tindak tutur ekspresif yang berupa tindak mengeluh dan mengkritik; tindak tutur komisif berupa tindak mengancam. Sementara itu, fungsi kesantunan menyenangkan dalam tindak tutur guru direpresentasikan dalam tindak tutur representatif berupa tindak mengharap; tindak tutur direktif berupa tindak mengklarifikasi, menyarankan, meminta, dan mempersilakan; tindak tutur ekspresif yang berupa tindak memuji-mengkritik dan tindak memuji; dan tindak tutur komisif yang berupa tindak berjanji

Untuk tindak tutur siswa, kedua fungsi kesantunan tindak tutur kompetitif dalam penelitian ini direpresentasikan ke dalam jenis tindak tutur direktif yang berupa tindak menantang, menuntut, menyuruh; dan tindak tutur ekspresif yang berupa tindak mengeluh dan mengkritik. Sementara itu, untuk fungsi kesantunan menyenangkan direpresentasikan ke dalam jenis tindak tutur direktif yang berupa tindak meminta dan menyarankan.

Fungsi kesantunan tindak tutur berbahasa Jawa yang ditemukan dalam penelitian ini, yaitu fungsi kompetitif dan fungsi menyenangkan. Menurut Leech (1993, pp.161-162), fungsi kompetitif terdapat dalam tindak tutur dimana tujuan ilokusinya bersaing dengan tujuan sosial. Pada fungsi kompetitif, kesantunan mempunyai sifat negatif dan dapat mengurangi ketidakharmonisan. Pada fungsi menyenangkan, kesantunan lebih bersifat positif. Fungsi menyenangkan ini digunakan untuk memperhalus tuturan dan 
menyenangkan pihak mitra tutur sehingga pada akhirnya akan menguatkan prinsip kerukunan.

Pada fungsi kesantunan kompetitif, nilai kesantunan tindak tutur direktif cenderung bersifat menurun karena kadar restriksi yang kuat sehingga pihak mitra tutur terlihat seperti dipaksa atau diharuskan menuruti tuturan penutur. Hal ini menyebabkan pihak mitra tutur mengalami kerugian dan kerukunan pun menjadi terancam. Pada tindak tutur ekspresif, nilai kesantunan cenderung bersifat menurun karena evaluasi yang diungkapkan penutur melalui tindak tutur ekspresif bersifat memberikan kerugian di pihak mitra tutur atau bahkan menyakiti perasaan mitra tutur. Pada tindak tutur komisif, nilai kesantunan cenderung bersifat menurun karena perbuatan yang mengikat penutur justru memberikan kerugian di pihak mitra tutur. Misalnya, pada tindak mengancam. Ancaman yang diungkapkan oleh penutur mengikat penutur untuk melakukan apa yang disebutkan dalam tuturannya tersebut. Tetapi isi tuturan yang disebutkan justru memberikan efek negatif atau merugikan kepentingan mitra tutur.

Pada fungsi kesantunan menyenangkan, nilai kesantunan tindak tutur representatif cenderung tinggi karena apa yang dinyatakan atau disebutkan dalam tuturan menyenangkan perasaan mitra tutur atau memberi keuntungan di pihak mitra tutur. Nilai kesantunan tindak tutur direktif cenderung tinggi karena meskipun terdapat kadar restriksi namun kadarnya tidak terlalu kuat sehingga pihak mitra tutur tidak dipaksa atau terlihat diharuskan menuruti tuturan penutur. Dibandingkan dengan tindak memerintah, tindak meminta memperlihatkan kadar restriksi perintah yang lebih tinggi daripada tindak meminta. Tindak meminta memperlihatkan pelunakan daya ilokusi sehingga tuturan terasa santun. Tindak memerintah yang disampaikan dalam bentuk ajakan membuat mitra tutur melaksanakan apa yang dituturkan oleh penutur berdasarkan kesediaan atau kesadarannya sendiri. Selain itu, tindak direktif menggunakan ungkapan penanda kesantunan seperti nyuwun tulung 'tolong', mangga 'silakan', ayo, dan sebagainya sehingga menambah nilai kesantunan berbahasa. Ungkapan penanda kesantunan ini juga membuat mitra tutur semakin merasa dihargai.

Tindak tutur ekspresif dengan fungsi kesantunan menyenangkan, nilai kesantunannya cenderung tinggi karena evaluasi diungkapkan menggunakan bahasa yang menyenangkan perasaan mitra tutur, atau meminimalisasi kerugian di pihak mitra tutur. Isi tuturan yang menyebabkan mitra tutur merasa senang akan menyelamatkan kerukunan antara penutur dan mitra tutur. Misalnya, pada tindak memuji-mengkritik. Pujian disampaikan guru mendahului kritikan (partial agreement) sehingga tidak menyakiti perasaan mitra tutur. Mitra tutur juga tidak kehilangan harga dirinya karena mengetahui bahwa dia masih mampu melakukan hal yang baik meskipun ada yang keliru. Pemberian kritikan memang penting, untuk melakukan koreksi. Namun, jangan sampai dilakukan dengan cara yang menghancurkan motivasi atau harga diri mitra tutur.

\section{Implikasi Hasil Penelitian Kesantunan Ber- bahasa Jawa dalam Interaksi Guru dan Siswa}

Pertama, penggunaan bentuk-bentuk kesantunan berbahasa Jawa baik oleh guru dan siswa untuk menyamankan dan memperlancar komunikasi dan interaksi dalam pembelajaran. Berdasarkan hasil penelitian dan pembahasan, penggunaan bentuk tindak tutur tidak langsung memiliki nilai kesantunan yang lebih tinggi daripada bentuk tindak tutur langsung, terutama untuk merepresentasikan tindak tutur direktif. Bentuk tindak tutur tidak langsung ini memberikan manfaat untuk memberikan kesempatan kepada penutur dan mitra tutur untuk 'mengamankan diri' sehingga akan terjaga hu-bungan kerukunan yang lebih baik. Pengamanan diri penutur mengacu kepada kondisi atau upaya agar penutur tetap 'selamat' jika tidak mendapat respon positif dari mitra tutur. Sementara itu, pengamanan diri mitra tutur mengacu kepada kondisi atau upaya agar mitra tutur tidak terkena daya ilokusi tuturan secara langsung sehingga memiliki keleluasaan untuk merespon. Kedua kondisi ini akan tetap menghasilkan suatu pengalaman yang menyenangkan meskipun penutur harus menuntut mitra tutur. Ketika interaksi antara guru dan siswa nyaman dan lancar, maka komunikasi akan berjalan efektif dan efisien sehingga tujuan pembelajaran pun dapat tercapai.

Kedua, peningkatan nilai kesantunan tuturan dengan memperhatikan isi tuturan yang berpihak pada mitra tutur disertai dengan penggunaan unggah-ungguh basa yang benar. Jika dilihat dari aspek isi tuturan, isi tuturan yang menghasilkan tuturan santun, yaitu tuturan yang berpihak pada mitra tutur. Hal ini dapat dicapai dengan pemberian perhatian, kepedulian, bantuan; tidak memaksakan kehendak; 
menghargai dan mengapresiasi usaha yang dilakukan mitra tutur meskipun hanya sedikit; dan pengungkapan maksud secara implisit atau tidak langsung agar mitra tutur tidak merasa tertekan. Pemberian perhatian, kepedulian, dan empati dari guru dan siswa dapat mendekatkan hubungan dan membangun rasa kekeluargaan.

Penggunaan unggah-ungguh basa yang tepat juga menentukan kesantunan suatu tuturan. Penggunaan unggah-ungguh basa ini menunjukkan sikap menghormati faktor sosial (terutama faktor usia dan situasi) yang melekat pada mitra tutur. Mengingat faktor sosial yang melekat pada guru, maka siswa menggunakan ragam bahasa krama inggil atau krama untuk berkomunikasi dan berinteraksi dengan guru. Sementara itu, guru sudah berusaha dengan sangat baik untuk menerapkan unggah-ungguh basa dalam interaksi di kelas.

Ketiga, penggunaan fungsi kesantunan menyenangkan dan ungkapan penanda kesantunan ketika akan melakukan tindak tutur direktif Fungsi kesantunan menyenangkan akan membuat tuturan lebih nyaman diterima oleh mitra tutur, terutama untuk tindak tutur direktif. Pada fungsi kesantunan menyenangkan, tindak tutur direktif disampaikan dengan menggunakan bentuk tindak meminta, menyarankan, dan mempersilakan yang memiliki daya ilokusi lebih lunak daripada tindak menyuruh. Fungsi ini akan membuat mitra tutur melaksanakan isi tuturan berdasarkan kemauan atau kesediannya sendiri, bukan karena tuntutan penutur.

Pada fungsi kesantunan menyenangkan, tuturan juga semakin santun dengan menggunakan ungkapan penanda kesantunan seperti cobi 'coba', nyuwun tulung 'minta tolong', suwun 'tolong', dan mangga 'silakan' untuk mengawali tindak tutur direktif. Selain itu dengan fungsi kesantunan menyenangkan, penutur (guru) dapat menyampaikan kritikan atau evaluasi dengan cara yang lebih santun dan tidak melukai perasan mitra tutur, yaitu dengan partial agreement atau persetujuan sebagian. Strategi partial agreement ini didahului dengan pujian untuk mengapresiasi usaha yang telah dilakukan siswa meskipun sedikit baru kemudian diikuti dengan koreksi. Strategi partial agreement ini akan membuat siswa tetap memiliki rasa percaya diri karena mengetahui dalam dirinya masih ada sisi positif yang patut untuk terus ditingkatkan. Strategi ini juga tidak akan mematikan motivasi dan harga diri siswa ketika guru menyampaikan evaluasi kritikan di depan siswa lain.

\section{SIMPULAN}

Bentuk kesantunan berbahasa guru dalam interaksi pembelajaran bahasa Jawa di SMP N 1 Banyumas, yaitu direpresentasikan dalam modus deklaratif atau berbentuk kalimat berita, modus interogatif atau berbentuk kalimat pertanyaan, dan modus imperatif atau berbentuk perintah. Bentuk kesantunan berbahasa siswa dalam interaksi pembelajaran bahasa Jawa di SMP $\mathrm{N} 1$ Banyumas, yaitu direpresentasikan dalam modus deklaratif atau berbentuk kalimat berita, modus interogatif atau berbentuk kalimat pertanyaan, modus imperatif atau berbentuk perintah.

Nilai kesantunan berbahasa dalam interaksi pembelajaran bahasa Jawa di SMP N 1 Banyumas dilihat dari isi tuturan guru dan siswa yang mematuhi prinsip kebijaksanaan, prinsip formalitas-tepa selira, prinsip penghargaan dan kerendahan hati-andhap asor, dan prinsip ketidaklangsungan. Nilai kesantunan berbahasa Jawa dalam interaksi pembelajaran bahasa Jawa di SMP N 1 Banyumas juga dilihat dari unggahungguh basa yang digunakan guru dan siswa ketika berinteraksi dalam pembelajaran bahasa Jawa.

Fungsi kesantunan tindak tutur berbahasa Jawa guru dalam interaksi pembelajaran bahasa Jawa di SMP N 1 Banyumas yang ditemukan dalam penelitian ini meliputi fungsi kompetitif dan fungsi menyenangkan. Fungsi kesantunan berbahasa ini direpresentasikan dalam bentuk tindak tutur representatif, direktif, ekspresif, dan komisif.

Berdasarkan temuan dan pembahasan penelitian maka diperoleh beberapa implikasi praktis yang terkait dengan pembelajaran. Implikasi tersebut, yaitu penggunaan bentuk-bentuk kesantunan berbahasa Jawa baik oleh guru dan siswa untuk menyamankan dan memperlancar komunikasi dan interaksi dalam pembelajaran, peningkatan nilai kesantunan tuturan dengan memperhatikan isi tuturan yang berpihak pada mitra tutur disertai dengan penggunaan unggahungguh basa yang benar, dan penggunaan fungsi kesantunan menyenangkan dan ungkapan penanda kesantunan ketika akan melakukan tindak tutur direktif (menyuruh, meminta, menyarankan, dan lain-lain) dan tindak ekspresif (mengkritik, memuji).

\section{DAFTAR PUSTAKA}

Brown, P. \& S. C. Levinson. (1987). Politeness: some universals in language usage. 
Cambridge: Cambridge University Press.

Eelen, G. (2001). A critique of politeness theories. Manchester: St. Jerome Publishing.

Gunarwan, Asim. (2005). Beberapa prinsip dalam komunikasi verbal: Tinjauan Sosiolinguistik dan Pragmatik. Dalam Pranowo, dkk. (Eds.), Bahasa, Sastra, dan Pengajarannya (1-18). Yogyakarta: Sanata Dharma University Press.

Harjawiyana, Haryana \& Supriya. (2009). Marsudi unggah-ungguh basa Jawa. Yogyakarta: Kanisius.

Leech, G. (1993). Prinsip-prinsip pragmatik. (Terjemahan MDD Oka). Jakarta: penerbit Universitas Indonesia.
Sugiyanto. (2011). Realisasi kesantunan berbahasa antara kepala sekolah dengan guru dan staf SMA Muhammadiyah 4 Andong. Tesis Magister, tidak diterbitkan, Universitas Muhammadiyah Surakarta.

Sukarno. (2010). The reflection of Javanese cultural concepts in the politeness Javanese. ProQuest, 12, 59-71.

Wang. (2008). The politeness effect: pedagogical agents and learning outcomes. Disertasi Doktor, tidak diterbitkan, University of Southern California.

Wardhaugh, R. (1986). An Introduction to Sociolinguistics. Cambridge: Blackwell Publisher. 